\title{
Corporate Behavior in the Petrochemical Industry
}

\author{
Shao-Ping Wang \\ Dept. of Business Management, Nunhua University \\ No.55, Sec. 1, Nanhua Rd., Dalin Township, Chiayi County 62249, Taiwan \\ E-mail: 10480006@nhu.edu.tw
}

Miao-Sheng Chen (Corresponding author)

Dept. of Business Management, Nunhua University

No.55, Sec. 1, Nanhua Rd., Dalin Township, Chiayi County 62249, Taiwan

E-mail:mschen@nhu.edu.tw

\author{
Mou-Jian Li (Corresponding author) \\ Dept. of Tourism Management, Nunhua University \\ No.55, Sec. 1, Nanhua Rd., Dalin Township, Chiayi County 62249, Taiwan \\ E-mail: mjlee@nhu.edu.tw
}

Received: Dec. 6, 2017 Accepted: Dec. 22, 2017 Online published: Jan. 2, 2018

doi:10.5296/ijhrs.v8i1.12236 URL: https://doi.org/10.5296/ijhrs.v8i1.12236

\begin{abstract}
Purpose

This case study, which investigates Taiwanese bellwether corporate groups in the petrochemical industry, explores employee observations and distinguishes these from general stakeholders' perspectives as organizational outsiders. The exploration involves in-depth discussions of the prevailing social atmosphere as environmental awareness emerges, and the linkages between corporate social responsibility (CSR), organizational commitment (OC), and organizational citizenship behavior (OCB).
\end{abstract}

Design

The study is based on models established by Taiwanese and international scholars addressing CSR's effects on OC and OCB. The study conducted a staff survey at several corporate 
groups' individual factories, selected using stratified sampling. Of 1,500 questionnaires distributed, 784 valid responses were collected. A five-point Likert scale was used to summarize data and conduct descriptive analysis, followed by confirmatory factor analysis and structural equation modeling.

\section{Findings}

With respect to the research hypotheses, the study finds that: (1) CSR has a significant and positive effect on OC; (2) CSR has a significant and positive effect on OCB; (3) OC has a significant and positive effect on OCB; and (4) CSR uses OC to generate an intermediary effect affecting OCB.

\section{Practical implications}

This study and its conclusions provide specific recommendations for industry and organizational insiders regarding how to fulfill CSR, improve OC, and achieve OCB.

Value

In an environment characterized by changing global socioeconomic conditions, this study provides academic and practical research recommendations for the petrochemical industry as well as recommendations for future research.

Keywords: business ethics, corporate social responsibility, organization behavior, organizational citizenship behavior, organizational commitment

\section{Introduction}

Petrochemical and gas sector firms are industry leaders in implementing corporate social responsibility (CSR) (Frynas, 2005). As petrochemical companies focus increasingly on their social and environmental impact, they continue to increase resource investments in their local communities. Given the significant impact that balancing environmental awareness with local economic development exerts on administrative policy development, civic groups generally oppose the petrochemical industry as a major source of environmental pollution. For this reason, in addition to developing recycling and equipment protection behaviors within their production processes to reduce their environmental impact, petrochemical companies participate in social welfare programs and sponsor community infrastructure projects to change perceptions of their industry.

The petrochemical industry has long faced public scrutiny over factory safety; air pollution; risks to neighboring residents; environmental, ecological, and land factors; and cultural shifts (Qiu, 2014). Zhao et al. (2016) contend that negative CSR activities, such as poor behavior with regard to the community, diversity, employee relations, and human rights, have harmed companies' operating performance. Therefore, this study uses the circumstances surrounding the petrochemical industry to explore the relationships between CSR, OC, and OCB. Using a questionnaire and a stratified sampling method targeted at employees throughout each plant, together with insider observer perspectives, this study produces conclusions and recommendations based on the analyzed content. 


\section{Literature Review and Research Hypotheses}

\subsection{Corporate Social Responsibility (CSR)}

Li (2016) views CSR as a set of obligatory restraints formed by different systems for different societal relationships with the firms. These restraints include: (1) governance mechanism requirements for firm contractors based on microcosmic systems (contracts); (2) legal obligations of the public contract system (the law) covering firm infringements of affected groups or individuals; and (3) ethical obligations to broader societal groups.

What benefits do companies derive from engaging in CSR? A literature review by Dan et al. (2016) found that companies benefit from CSR in seven ways: (1) increased profits; (2) increased value and stock return rates; (3) decreased risk; (4) increased number of stakeholders (employees, customers, suppliers, shareholders) optimistic about the company's future; (5) decreased capital costs; (6) decreased information asymmetry and improved corporate image of integrity; and (7) increased competitiveness. Regarding functionality, CSR promotes a company's external competitiveness as it can generate commercial advantages by improving internal cohesion, increasing motivated morale, and attracting and retaining talent. Simultaneously, CSR boosts brand image and improves business reputation. Furthermore, it helps societies coordinate economic, social, and environmental development, while enhancing competitiveness and problem-solving skills. For example, companies can recruit workers from disadvantaged groups or regions to resolve social issues and can use the power of transnational companies to promote industry strategies or standards for environmental protection.

\subsection{Organizational Commitment $(O C)$}

OC refers to the psychological connection between an individual and an organization, which includes emotional attachment, loyalty, and willingness to become a member of an organization (Judge and Kammeyer-Mueller, 2012). OC can create helpful connections between individuals and organizations, and produce positive outcomes for individuals, organizations, and societies (Mowday et al., 1979). Organization members have high levels of positive tendencies towards their organizations and tend to identify with their organization's objectives and values (Trimble, 2006). Moss et al. (2007) and Mowday et al. (1979) recognize that OC is defined by an organization's employee's strong belief in and acceptance of organizational objectives and values as well as the employee's willingness to devote extra effort towards attaining organizational objectives in the hope of becoming a member. They further distinguish between the following dimensions of OC: value commitment (a strong conviction for accepting organizational objectives and values), effort commitment (the willingness to expend extra effort on organizational interests), and continuance commitment (the willingness to remain within the organization). Employees with high OC levels less frequently leave their jobs or arrive late to work. Moreover, they are actively committed to playing regular or creative roles. OC exhibits a positive correlation with altruism in OCB (Mowday et al., 1982; Gartam et al., 2005).

Similar to the dimensions above, Allen and Meyer (1990) propose that the scale for measuring OC comprises emotional commitment, continuance commitment, and normative 
commitment (Meyer and Allen, 1984). Here, continuance commitment primarily stems from Kanter's (1968) cost perspective, which asserts that employees remain with organizations to avoid the high costs of transferring elsewhere. Emotional commitment is derived from Etzioni's (1975) ethical investment perspective and Kanter's (1968) cohesive commitment viewpoint. Normative commitment is based on Wiener's (1982) internalized normative pressure perspective. In addition, Wang (2004) studied these commitments in ethnic Chinese employees by developing a scale to measure OC in the Chinese context, which included emotional, sustainable, normative, and value commitments. This study applies the Allen and Meyer (1990) scale for its exploration (Meyer and Allen, 1984).

\subsection{Organizational Citizenship Behavior (OCB)}

Katz (1964) was the first to propose research on OCB. His study stated that employees exhibit three types of behavior that can affect organizational performance: (1) entrance behavior - referring to employees' entry into the organization, which may reduce absenteeism and turnover; (2) role performance behavior - referring to employees' duties as set out in their job specifications; and (3) voluntary behaviors-referring to employees proactively carrying out contributive behaviors that exceed their professional roles. Barnard (1938), Bateman and Organ (1983), Robinson and Morrison (1995), Robbins (2001), Somech and Ron (2007), and Williams and Anderson (1991) explain that OCB includes the active assistance of coworkers, active participation in organizational topics, and the active performance of duties outside of one's role. Voluntary actions to achieve organizational objectives also effectively improve organizational efficacy and efficiency. Organ (1988) defines OCB as the voluntary behaviors of individuals in an organization. Though an organization's incentive system cannot directly or officially affirm this behavior, it is helpful in achieving organizational objectives. Organ and Konovsky (1989) state that OCB should include such instances as when employees exert self-control to avoid engaging in negative behaviors; they also argue that OCB entails instances in which employees not only fulfill unofficial work requirements but also behave in ways that can improve organizational efficiency.

Graham (1991) contends that all behaviors beneficial to the organization can be referred to as OCB; therefore, this definition includes all positive behaviors by individual organization members and those related to the organization. Williams and Anderson (1991) classify OCB as either "organization-based citizenship behavior" (indicating employees' vigorous efforts in the pursuit of organizational interests) or "individual-based citizenship behavior" (workers' concern for and willingness to assist others, which indirectly benefits the organization). Overall, for each classification, most tend to consider factors embodying such perspectives as spontaneity, altruism, and identification with the organization.

\section{Research Hypotheses}

Empirical research by Brammer et al. (2007) shows that a positive OC reaction is generated in employees when they understand their company has fulfilled social obligations. Collier and Esteban (2007) discovered that when companies fulfill their social responsibilities by committing to CSR, employees have a higher OC level. Regarding the relationship between 


\section{Ml Macrothink}

International Journal of Human Resource Studies

ISSN 2162-3058

2018, Vol. 8, No. 1

CSR and OC, 58\% of employees reported their organization's engagement in CSR to be an important determinant of their willingness to exert effort for their employer (Dawkins, 2004).

CSR encompasses all activities conducted to comply with social values and maintain public support. Employees exist in an environment that shares the organization's sense of social justice, compassion, and empathy. This environment personally impacts employees and, thereby, impacts organizational environmental identification and maintenance, as well as OCB related to caring about and offering suggestions to improve the organization, reducing conflict with colleagues, and protecting organizational resources. A study by Zhou and $\mathrm{Wu}$ (2010) identified the positive and significant impact of CSR on OCB. The empirical results indicate that employees' perceptions of CSR practices have a positive impact on their OC and OCB (Choi and Yu, 2014).

Furthermore, Williams and Anderson (1992) propose that OC is a good predictor of whether individuals will perform actions outside their roles, positing that OC indicates an employee's sense of belonging to an organization and is connected with OCB. In addition, OC promotes organizational efficacy and efficiency, which are the outcomes of investing in proper resource allocation and innovative behaviors. From this, it is clear that OC is significantly correlated with OCB. Yang (2004) recognizes that work satisfaction and OC significantly affect employees' OCB. In their study, Zhou and Chen (2009) found that OC positively and significantly affects OCB, endorsing Chen and Yuan's (2007) earlier study. Similarly, Liao et al. (2014) reveal that employees' OC is positively and significantly correlated with their OCB. The OCB partially mediates the relationship between CSR practices and organizational performance, whereas OC indirectly mediates the relationship only through OCB (Choi and Yu, 2014). Yoon et al.'s (2016) research indicated that OC fully mediated the relationship of OCB, while Fu et al.'s (2014) indicated that CSR influences OCB through the mediating effects of OC.

Thus, according to the reasoning detailed above, this study proposes and tests the following research hypotheses (see Figure 1):

H1: CSR has a positive and significant effect on OC.

H2: CSR has a positive and significant effect on OCB.

H3: OC has a positive and significant effect on OCB.

H4: OC mediates the effect of CSR on OCB.

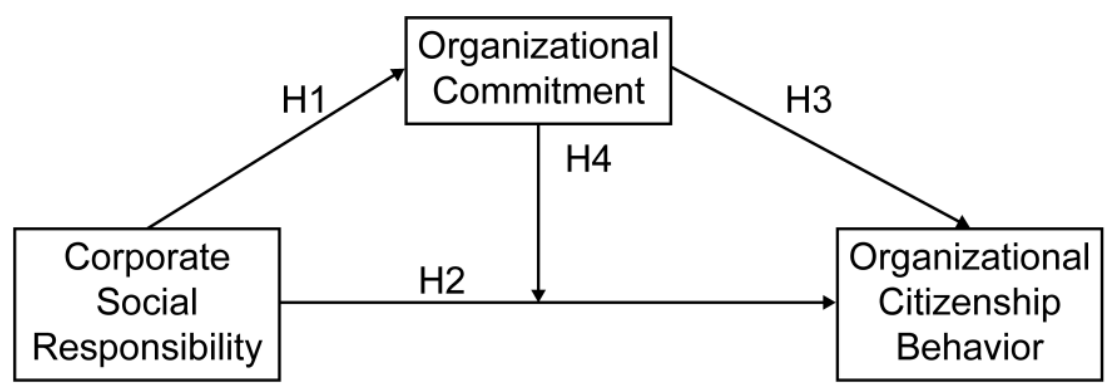

Figure 1. The Research Structure. 


\section{Research Subjects and Data Collection}

This study's research subjects are employees in the Taiwanese petrochemical industry. The study used social contacts for sampling, which was performed using the stratified sampling method. The survey was conducted through a questionnaire. Based on an initial population of 12,000 employees working for 13 companies in the selected industrial park and valid sample values, questionnaires - completed anonymously-were distributed to 1,500 voluntary participants (Dillman, 2000). The questionnaire was developed based on the existing literature, and its content comprised four sections. The first section included a scale to measure CSR that examined four elements of responsibility-economic, legal, moral, and discretionary (Carroll, 1979). The second section comprised a scale to measure OC, which included Tsai (2001) and Allen and Meyer's (1990) three OC elements: morality, emotion, and sustainability. The third section comprised a scale to measure OCB, which included Xie (2003) and Williams and Anderson's (1991) three OCB elements: role performance behavior, altruistic behavior, and organizational public welfare behavior. The fourth section included basic personal information. The survey was conducted during October and November 2016. Of the 1,500 questionnaires distributed, 812 were collected, yielding a return rate of $54.13 \%$. Of these, 784 questionnaires (52.26\% of the total distributed) were valid. Regarding the question item measurement methods, the first, second, and third sections offered a five-point Likert scale, which asked respondents to state their level of agreement. The fourth section used a nominal scale.

This study used the main structural components of variables to conduct the analysis. The partial least squares structural equation modeling method (PLISSE) was applied. Furthermore, we used SmartPLS3 software to conduct our analysis. In comparison to covariance-based SEM for variables (which often uses LISREL or AMOS software), PLS_SEM places relatively low requirements on measurement scales, sample size, and residual distributions. PLS_SEM interprets variance (testing whether the causal relationship is statistically significant) and is suitable for establishing theoretical (exploratory) models. Furthermore, it can be used to verify deduced causal relationships (Xiao, 2016).

\section{Empirical Analysis and Results}

\subsection{Descriptive Statistics of Sample Data}

As shown in Table 1, most of the questionnaire respondents were male ( $84.6 \%$ of the total). The proportion of married respondents was relatively high $(68 \%)$. Age was concentrated around the 31-50 years range, accounting for $68.5 \%$ of the total respondents. Most respondents $(63.5 \%)$ were entry-level employees and had a university or college education $(55.5 \%)$. The largest number of respondents had served in their current organization for more than 16 years, while the next largest group had served for less than five years. These two groups constituted $69.7 \%$ of the total. 
Table 1. Sample Data Statistics

\begin{tabular}{|c|c|c|c|c|c|}
\hline \multicolumn{2}{|c|}{ Variable } & Proportion & \multicolumn{2}{|c|}{ Variable } & Proportion \\
\hline \multirow{2}{*}{ Gender } & Male & $84.6 \%$ & \multirow{3}{*}{ Marital Status } & Unmarried & $28.1 \%$ \\
\hline & Female & $15.4 \%$ & & Married & $68.0 \%$ \\
\hline \multirow{5}{*}{ Age } & 20 or younger & $0.3 \%$ & & $\begin{array}{l}\text { Previously } \\
\text { Married }\end{array}$ & $3.9 \%$ \\
\hline & $21-30$ & $24.7 \%$ & \multirow{4}{*}{ Job Title } & $\begin{array}{l}\text { Entry-Level } \\
\text { Employee }\end{array}$ & $63.5 \%$ \\
\hline & $31-40$ & $32.8 \%$ & & $\begin{array}{l}\text { Entry-Level } \\
\text { Supervisor }\end{array}$ & $31.0 \%$ \\
\hline & $41-50$ & $35.7 \%$ & & $\begin{array}{l}\text { Middle } \\
\text { Supervisor }\end{array}$ & $3.9 \%$ \\
\hline & 51 or older & $6.5 \%$ & & $\begin{array}{c}\text { Senior } \\
\text { Supervisor }\end{array}$ & $1.6 \%$ \\
\hline \multirow{4}{*}{ Education } & $\begin{array}{l}\text { Middle School } \\
\text { or Below }\end{array}$ & $1.0 \%$ & \multirow{4}{*}{$\begin{array}{c}\text { Years of Employment } \\
\text { in Current } \\
\text { Organization }\end{array}$} & $0-5$ Years & $29.9 \%$ \\
\hline & $\begin{array}{l}\text { High School/ } \\
\text { Vocational }\end{array}$ & $32.8 \%$ & & 6-10 Years & $12.6 \%$ \\
\hline & $\begin{array}{l}\text { University/ } \\
\text { College }\end{array}$ & $55.5 \%$ & & $11-15$ Years & $17.7 \%$ \\
\hline & $\begin{array}{l}\text { Graduate } \\
\text { School }\end{array}$ & $10.7 \%$ & & Over 15 Years & $39.8 \%$ \\
\hline
\end{tabular}

\subsection{Scale Reliability and Validity Analysis}

Reliability encompasses stability and consistency. Cronbach's $\alpha$ for each dimension of the questionnaire in this study was greater than 0.70, showing that the measurement scale for each element had relatively good reliability. Furthermore, a confirmatory factor analysis (CFA) explored the composite reliability (CR) of potential variables. Table 2 shows that the reliability value for each element is greater than the suggested value of 0.7 (Hair et al., 1998), indicating that the reliability of each element in this study is quite high. 
Table 2. Results of the Reliability and Validity Analysis and Confirmatory Factor Analysis

\begin{tabular}{|c|c|c|c|c|c|}
\hline Element & $\begin{array}{l}\text { Question } \\
\text { Item }\end{array}$ & Factor Load & Cronbach's $\alpha$ & $\mathrm{CR}$ & AVE \\
\hline \multirow{7}{*}{$\begin{array}{l}\text { Corporate } \\
\text { Social } \\
\text { Responsibility }\end{array}$} & CSR1 & 0.723 & \multirow{7}{*}{$0.924 * * *$} & \multirow{7}{*}{$0.939 * * *$} & \multirow{7}{*}{$0.669 * * *$} \\
\hline & CSR2 & 0.850 & & & \\
\hline & CSR3 & 0.885 & & & \\
\hline & CSR4 & 0.876 & & & \\
\hline & CSR5 & 0.843 & & & \\
\hline & CSR6 & 0.809 & & & \\
\hline & CSR7 & 0.817 & & & \\
\hline \multirow{3}{*}{$\begin{array}{l}\text { Organizational } \\
\text { Commitment }\end{array}$} & OP1 & 0.868 & \multirow{3}{*}{$0.797 * * *$} & \multirow{3}{*}{$0.881 * * *$} & \multirow{3}{*}{$0.740 * * *$} \\
\hline & OP2 & 0.875 & & & \\
\hline & OP3 & 0.785 & & & \\
\hline \multirow{6}{*}{$\begin{array}{l}\text { Organizational } \\
\text { Citizenship } \\
\text { Behavior }\end{array}$} & OCB1 & 0.888 & \multirow{6}{*}{$0.929 * * *$} & \multirow{6}{*}{$0.944 * * *$} & \multirow{6}{*}{$0.712 * * *$} \\
\hline & OCB2 & 0.871 & & & \\
\hline & OCB3 & 0.884 & & & \\
\hline & OCB4 & 0.868 & & & \\
\hline & OCB5 & 0.789 & & & \\
\hline & OCB6 & 0.856 & & & \\
\hline
\end{tabular}

Regarding validity, the questionnaire items for each measurement element were adopted from previous studies' measurement scale items, complying with the standards for content validity. To test convergent validity, the methods recommended by Anderson and Gerbing (1988) were used; therefore, the factor load of the observed variable must reach an f-loading $>0.7$ to have statistical significance. This study used standardized factor loading for each variable, as required by CFA, which ranges between 0.723-0.888; therefore, reaching the level of statistical significance. This shows that the observed variables can all effectively converge on the factors to which they are attributable; therefore, this measurement scale has convergent validity. Regarding discriminate validity, the square root of each element should be greater than the correlation coefficient of any two elements. As shown in Table 3, all correlation coefficients between variables are less than 0.8 , and collinearity has not been generated. Furthermore, the square roots of the average variance extracted (AVE) values are all greater than the correlation coefficient between each element and other elements; thus, this study's measures pass validity testing. 
Table 3. Element Correlation Coefficients

\begin{tabular}{l|c|c|c|c}
\hline Item & AVE & $\begin{array}{c}\text { Corporate Social } \\
\text { Responsibility }\end{array}$ & $\begin{array}{c}\text { Organizational } \\
\text { Commitment }\end{array}$ & $\begin{array}{c}\text { Organizational } \\
\text { Citizenship Behavior }\end{array}$ \\
\hline $\begin{array}{l}\text { Corporate Social } \\
\text { Responsibility }\end{array}$ & 0.669 & 1 & & \\
\hline $\begin{array}{l}\text { Organizational } \\
\text { Citizenship Behavior }\end{array}$ & 0.740 & 0.693 & 1 & 1 \\
\hline $\begin{array}{l}\text { Organizational } \\
\text { Commitment }\end{array}$ & 0.712 & 0.650 & 0.640 & \\
\hline
\end{tabular}

\subsection{Empirical Results}

Table 4 provides the test results for this study's model. Below, we further analyze and explain the empirical results. The study's empirical results support the notion that CSR has a statistically significant effect on OC $(\gamma 11=0.480)$. This is consistent with Brammer et al. (2007) and Collier and Esteban (2007), who propose that when employees believe that their company is fulfilling social responsibilities, their OC is enhanced. Therefore, $\mathrm{H} 1$ is supported.

Table 4. Results of the Structural Model Test

\begin{tabular}{ccccc}
\hline Path Relationship & $\begin{array}{c}\text { Path } \\
\text { Coefficient }\end{array}$ & $\begin{array}{c}\text { Standard } \\
\text { Error }\end{array}$ & $t$-value & $\begin{array}{c}\text { Hypothesis } \\
\text { Supported (Yes/No) }\end{array}$ \\
\hline CSR->OP $\gamma 11(\mathrm{H} 1)$ & $0.480 * * *$ & 0.057 & 8.355 & Yes \\
CSR->OCB $\gamma 21(\mathrm{H} 2)$ & $0.650^{* * *}$ & 0.033 & 19.877 & Yes \\
OP->OCB $\beta 31(\mathrm{H} 3)$ & $0.328 * * *$ & 0.057 & 5.732 & Yes \\
CSR->OCB (H4) & $0.213^{* * *}$ & 0.038 & 5.674 & Partial Mediation \\
\hline
\end{tabular}

Note: $*=\mathrm{p}<0.1 * *=\mathrm{p}<0.05 * * *=\mathrm{p}<0.01$

Regarding the effect of CSR on OCB, the study's results reveal a positive and significant effect $(\gamma 21=0.650)$, indicating that when a company engages in CSR, a sense of affirmation is generated for employees, who will then assist and cooperate with colleagues. Therefore, $\mathrm{H} 2$ is supported. Analysis of the respondents' employment history data showed that the largest proportion of respondents had at least 16 years in their current organization (39.8\%): these employees were more likely to have greater coherence with their company than the other respondents. In addition to proving the hypothesis, this also reflects that the studied corporate groups have established their rank as bellwether (or market leader) companies. Supporting $\mathrm{H} 2$, the results reveal a significant and positive effect of CSR on OCB.

The effect of OC on OCB is statistically significant $(\beta 31=0.328)$, mirroring Munene's (1995) proposal that OC is positively and significantly correlated with OCB. Therefore, $\mathrm{H} 3$ is supported. Analysis of the respondents' education-level data showed that the highest proportion had graduated from university/college $(55.5 \%)$, indicating that a large proportion of the studied organizations' employees have relatively strong learning and innovation abilities, and that they may be equipped to grasp and actively respond to socioeconomic 
conditions. This supports H2. The effect of OC on OCB (H3) was also statistically significant.

It is also necessary to consider indirect effects, as direct effects are influenced by mediating variables. Based on the indirect, direct, and aggregate effects of CSR and OCB in the aggregate model, the total effect of CSR is 0.48 , while the indirect effect is 0.213 , or $44.4 \%$ of the total effect. This clarifies that OC mediates the effect of CSR on employee OCB (see Table 4). Analysis of the respondents' age data shows the greatest proportion of respondents were 41-50 years old (35.7\%). Such employees are at a stage of physical and mental maturity in which they take on important responsibilities in their households and roles in society. This can effectively lead them to greater engagement in OCB as their OC is more likely to be recognized by the organization with increased salaries or benefits. This also proves the mediator effect hypothesis (H4).

\section{Conclusions and Recommendations}

This study examined Taiwan's petrochemical industry to research the effects of CSR and OC on employee OCB. In addition to exploring these effects, it also tested the indirect mediator mechanisms involved therein. Below, we present conclusions based on this study's descriptive statistics, variable analysis, and hypothesis testing. In addition, we discuss the management implications of the theoretical developments, practical applications of this study's discoveries, limitations of this study's conclusions, and future avenues of CSR, OC, and OCB research.

\subsection{Practical Discussion and Recommendations for Management}

This study focused on petrochemical corporate groups established over half a century ago, whose business models have been implemented worldwide. Though rooted in the traditional manufacturing sector and now facing the ever-increasing challenges of greater environmental awareness and demands for sustainable business operations, these business owners - embracing the spirit of giving back to the community - are sparing no effort to protect local environments and disadvantaged groups. Recently, by coordinating with neighboring community religious celebrations to host "Factories and Towns as Families" events, firms have spent huge sums of money designing software and hardware to assist the managers of temples and public offices with various event logistics (China Times, 2017). During these events, factory tours, product promotions, and parent-child activities are integrated into the religious pilgrimages. In addition to employees, more than 1,000 other people participate in these events, which are widely reported in the media and positively reviewed. In addition to factory workers, employees from all departments actively participate in these events, helping to promote a positive corporate image. Clearly, such corporate strategies for CSR and sustainable development have already had some success.

In theory, this study's findings echo the conclusion of Brammer et al. (2007) that when employees believe that their company is fulfilling its social responsibilities, this generates a positive effect in their OC. Furthermore, Collier and Esteban (2007) found that implementing CSR generates a large and positive effect on OC, meaning that if firms fulfill their social 
responsibilities, employees will have higher levels of OC. Thus, this study's hypothesis that CSR has a significant and positive effect on OC (H1) is supported. Furthermore, engaging in CSR has a positive and significant effect on employee OCB (supporting H2). Therefore, we can deduce that by pursuing societal values-thereby forming a positive corporate image-and providing a working environment that supports social justice, compassion, and empathy, firms may have an exemplary effect on their employees, which, in turn, influences employee behavior and affirms the organizational environment. Based on the statistics on the mediated (indirect) relationship, we see that OC mediates the effects of CSR on OCB. Thus, in this study's model, employees' OC may be enhanced through company implementation of multi-faceted efforts to improve employee care and benefits and internal systems.

The study also demonstrates that OC has a positive and significant effect on OCB; thus, supporting H3. This echoes the argument of Bateman and Strasser (1984), who state that when an employee has high OC, they strengthen their knowledge and understanding of the organization's internal affairs. Similarly, O'Reilly and Chatman (1986) note that OC is positively and significantly correlated with employees acting beyond their roles. In such circumstances, employees are willing to expend extra effort for their organization, and view organizational interests as their own - they work hard for these interests and, thereby, display OCB. This reiterates the conclusions of Alotaibi (2001), which proffered positive correlations between $\mathrm{OC}$ and interpersonal assistance, diligence, personal initiative, loyalty, and conscientiousness. Furthermore, Mohammad and Javad (2011) and Sayyed et al. (2011) assert that when identifying with an organization, where high levels of OC cause one to prioritize organizational interests, employees will display OCB through hard work, courtesy, teamwork, active assistance of others, and altruism.

Thus, regarding management practices, to improve OC toward their companies and actively display OCB, managers should consider ways in which they can reduce problematic factors, like staff conflicts and role confusion, and ensure that employees identify with their company through its actions. Such efforts could be achieved by reducing employee work and socioeconomic pressures, assisting employees in career planning to improve their work skills and self-confidence, clearly conveying work expectations to employees, and establishing a suggestion discussion platform. Consequently, through these efforts, employees will sense their company's diligence. Furthermore, executing CSR improves a company's image and increases its employees' social perception regarding their work. In turn, employees are more willing to support their company and maintain its reputation, thereby helping to achieve the objective of sustainable operating growth.

\subsection{Limitations and Future Research}

Although this study's analysis and conclusions may have far-reaching implications for global company management, sustainability, and organizational practice, one must take into account that this study's investigation was limited to Taiwan's petrochemical industry. The issues facing Taiwan's petrochemical industry may be peculiar to the region and the industry. Thus, as this particular industry, which generates pollution and burdens certain social groups, demands significant improvements to environmental protection and social justice efforts, the 
implications of organizational practice from this perspective may not precisely align with the practices of other industries or other regions.

Accordingly, to confirm that these study's findings are suitable for application on a more global regional scale as well as a more diverse industrial scale, further research in other regions and industries is necessary. For instance, future investigations should include research on technological and waste disposal industries, both of which are environmentally detrimental and highly controversial.

\section{Acknowledgement}

Thanks for Prof. Miao-Sheng Chen and Prof. Mou-Jian Li, Nanhua University.

\section{References}

Allen, N. J., \& Meyer, J. P. (1990). The measurement and antecedents of affective, continuance and normative commitment to the organization. Journal of Occupational and Organizational Psychology, 63(1), 1-18. https://doi.org/10.1111/j.2044-8325.1990.tb00506.x

Alotaibi, A. G. (2001). Antecedents of organizational citizenship behavior: A study of public personnel in Kuwait/5 Public Personnel Management, 30(3), 363375. https://doi.org/10.1177/009102600103000306

Anderson, J. C., \& Gerbing, D. W. (1988). Structure equation model in practice: a review and recommended two-step approach. Psychological Bulletin, 103(3), 411-423. https://doi.org/10.1037/0033-2909.103.3.411

Barnard, C. I. (1938). The Functions of the Executive, Harvard University Press, Cambridge, MA.

Bateman, T. S., \& Organ, D. W. (1983). Job satisfaction and the good soldier: The relationship between affect and employee 'citizenship'. Academy of Management Journal, 24(4), 587-595. https://doi.org/10.2307/255908

Bateman, T. S., \& Strasser, S. A. (1984). A longitudinal analysis of the antecedents of organizational commitment. Academy of Management Journal, 27(1), 95-112. https://doi.org/10.2307/255959

Blowfield, M., \& Frynas, J. G. (2005). Editorial Setting new agendas: critical perspectives on Corporate Social Responsibility in the developing world. International affairs, 81(3), 499-513. https://doi.org/10.1111/j.1468-2346.2005.00465.x

Brammer, S., Millington, A., \& Rayton, B. (2007). The contribution of corporate social responsibility to organizational commitment. The International Journal of Human Resource Management, 18(10), 1701-1719. https://doi.org/10.1080/09585190701570866

Carroll, A. B. (1979). A three-dimensional conceptual model of corporate performance. Academy of management review, 4(4), 497-505.

Chen, G., \& Yuan, R. (2007). Relationship between Direct Selling Job Pressure, Work 
Satisfaction, Organizational Commitment, and Organizational Citizenship Behavior. Direct Selling Management Review, 1(1), 137-59.

China Times. (2017). Thousands Feel Comforted about Environmental Protection in the Sixth Naptha Cracking Plant. Retrieved April 16, 2017 from http://www.chinatimes.com/newspapers/20170416000351-260107.

Choi, Y., \& Yu, Y. (2014). The influence of perceived corporate sustainability practices on employees and organizational performance. Sustainability, 6(1), 348-364. https://doi.org/10.3390/su6010348

Collier, J., \& Esteban, R. (2007). Corporate Social Responsibility and Employee Commitment. Business Ethics: A European Review, 16(1), 19-33. https://doi.org/10.1111/j.1467-8608.2006.00466.x

Dan, Y., Ke, W., \& Chi, X. (2016). What Benefits Can CSR Bring to Corporate Operating Strategy? Evidence from Top-Tier Global Journals. International Journal of Commerce and Strategy, 8(2), 77-86.

Dawkins, J. (2004). The Public's Views of Corporate Responsibility 2003. Peterson, DK: MORI.

Dee, J. R., Henkin, A. B., \& Singleton, C. A. (2006). Organizational Commitment of Teachers in Urban Schools: Examining the Effects of Team Structures. Urban Education 41(6), 603-27. https://doi.org/10.1177/0042085906292512

Dillman, D. A. (2000). Mail and Internet Surveys: The Tailored Design Method (2), New York: Wiley.

Etzioni, A. (1975). A Comparative Analysis of Complex Organizations. New York: Macmillan.

Fu, H., Ye, B. H., \& Law, R. (2014). You do well and I do well? The behavioral consequences of corporate social responsibility. International Journal of Hospitality Management, 40, 62-70. https://doi.org/10.1016/j.ijhm.2014.03.004

Gartam, T., Van Dick, R., Wagner, U., Upadhyay, N., \& Davis, A. J. (2005). Organizational Citizenship Behavior and Organization Commitment in Nepal. Asia Journal of Social Psychology, 8(3), 305-314. https://doi.org/10.1111/j.1467-839X.2005.00172.x

Graham, J. W. (1991). An Essay on Organizational Citizenship Behavior, Employee Responsibilities and Rights Journal, 4(4), 249-270. https://doi.org/10.1007/BF01385031

Hair, J. F., Black, W. C., Babin, B. J., Anderson, R. E., \& Tatham, R. L. (1998). Multivariate Data Analysis. Upper Saddle River, NJ: Prentice Hall.

Jaramilo, F., Mulki, J. P., \& Marshall, G. W. (2005). A Meta-Analysis of the Relationship between Organizational Commitment and Salesperson Job Performance: 25 Years of Research. Journal of Business Research, 58(6), 705-725. https://doi.org/10.1016/j.jbusres.2003.10.004 
Jiang, X. (2009). The Relationship between Corporate Social Responsibility, Organizational Commitment, and Organizational Citizenship Behavior. Master's Thesis, Southern Taiwan University of Technology, Graduate Institute of Technological and Vocational Education and Human Resource Development.

Judge, T. A., \& Kammeyer, M. J. D. (2012). Job Attitudes. Annual Review of Psychology, 63, 341-367. https://doi.org/10.1146/annurev-psych-120710-100511

Kanter, R. M. (1968). Commitment and Social Organization: A Study of Commitment Mechanisms in Utopian Communities. American Sociological Review, 33, 499-517. https://doi.org/10.2307/2092438

Katz, D. (1964). The motivational basis of organizational behavior', Behavior Science, 9(2), 131-46. https://doi.org/10.1002/bs.3830090206

Li, W. (2016). Economic analysis of corporate social responsibility systems. The Academic Journal for Corporate Social Responsibility, 1(1), 7-24.

Li, Y., Chen, H., \& Xu, F. (2014). Sports center employee work satisfaction, organizational commitment, and turnover tendencies. Fujen University Physical Education Journal, 13, 236-266.

Liao, M., Wen, F., \& Tang, M. (2014). Cross-level research on the impact of organizational commitment on public sector organizational citizenship behavior: Using leadership style changes as regulator variables. Sun Yat Sen Management Review, 22(3), 429-468.

Meyer, J. P., \& Allen, N. J. (1984). Testing the side-bet theory of organizational commitment: some methodological considerations. Journal of Applied Psychology, 69, 372-378. https://doi.org/10.1037/0021-9010.69.3.372

Mohammad, H. M. J., \& Javad, Y. (2011). Effect of organizational identity and commitment on organizational citizenship behavior. Interdisciplinary Journal of Contemporary Research in Business, 3(2), 100-112.

Moss, S. A., McFarland, J., Ngu, S., \& Kijowska, A. (2007). Maintaining an open mind to closed individuals: The effect of resource availability and leadership style on the association between openness to experience and organizational commitment. Journal of Research in Personality, 41(2), 259- 275. https://doi.org/10.1016/j.jrp.2006.03.009

Mowday, R. T., Porter, L. W., \& Steers, R. M. (1979). The measurement of organizational commitment. Journal of Vocational Behavior, 14, 224-247. https://doi.org/10.1016/0001-8791(79)90072-1

Mowday, R. T., Porter, L. W., \& Steers, R. M. (1982), Employee-Organization Linkages: The Psychology of Commitment, Absenteeism, and Turnover, Academic Press, San Diego, CA.

Munene, J. C. (1995). Not-on-seat: An investigation of some correlates of organizational citizenship behavior in Nigeria. Applied Psychology: An International Review, 44(2), 111-122. https://doi.org/10.1111/j.1464-0597.1995.tb01069.x 
O'Reilly, C. A., \& Chatman, J. A. (1986). Organizational commitment and psychological attachment: The effects of compliance, identification, and internalization on pro-social behavior. Journal of Applied Psychology, 71, 492-499. https://doi.org/10.1037/0021-9010.71.3.492

Organ, D. W. (1988). Organizational Citizenship Behavior: The Good Soldier Syndrome, Lexington Books, Massachusetts.

Organ, D. W., \& Konovsky, M. A. (1989). Cognitive versus affective determinants of organizational citizenship behavior. Journal of Applied Psychology, 74(1), 157-64. https://doi.org/10.1037/0021-9010.74.1.157

Qiu, R. (2014). The influence of Formosa Plastic's sixth naphtha cracking plant on the overall socioeconomic development of Yunlin County, Taiwan: Discussion on the corporate social responsibility practices of Formosa Plastics' sixth naphtha cracking plant. Journal of Global Management and Economics, 10(1), 34-52.

Robbins, S. P. (2001). Organizational Behavior (9th ed.), Prentice-Hall, Upper Saddle River, New Jersey.

Robinson, S. L., \& Morrison, E. W. (1995). Psychological contracts and OCB: The effect of unfulfilled obligations on civic virtue behavior. Journal of Organizational Behavior, 16(3), 289-298. https://doi.org/10.1002/job.4030160309

Sayyed, M. A., Samane, A., \& Ali, A. (2011). A survey of relationship between organizational commitments and organizational citizenship behavior. Interdisciplinary Journal of Contemporary Research in Business, 3(5), 360-368.

Securities and Futures Institute. (2015). Corporate Social Responsibility: A Case Study of Outstanding Achievements, Securities and Futures Institute, Taipei.

Somech, A., \& Ron, I. (2007). Promoting organizational citizenship behavior in schools: The impact of individual and organizational characteristics. Educational Administration Quarterly, 43(1), 38-66. https://doi.org/10.1177/0013161X06291254

Thompson, F. L. (1989). The relationship between leadership style and organizational commitment in selected Wisconsin elementary schools. Dissertation Abstracts International, 51/514A, University of Wisconsin--Madison.

Trimble, D. E. (2006). Organizational commitment, job satisfaction, and turnover intention of missionaries. Journal of Psychology and Theology, 34(4), 349-60.

Tsai. (2001). A study on the impact of ethical climate cognition and organizational commitment on organizational citizenship behavior: A case study of chunghwa telecom's new camp and jiali operations department. Doctoral dissertation, Pai-Chang Tsai.

Wang, Y. (2004). Observations on the organizational commitment of Chinese employees: comparative studies of state-owned enterprises and foreign-invested enterprises. International Journal of Human Resource Management, 15(4), 649-669. 
https://doi.org/10.1080/0958519042000192889

Wiener, Y. (1982). Commitment in organizations: A normative view. Academy of Management Review, 7(3), 418-428.

Williams, L. J., \& Anderson, S. E. (1991). Job satisfaction and organizational commitment as predictors of organizational citizenship and in-role behaviors. Journal of Management, 17(3), 601-617. https://doi.org/10.1177/014920639101700305

Williams, L. J., \& Anderson, S. E. (1992). An alternative approach to method effects using latent variable models: Applications in organizational behavior research. Meeting of the Academy of Management, Las Vegas University Press, Las Vegas, NV.

Xiao, W. (2016), Introduction to Statistical Analysis and Application: SPSS Chinese Version and SmartPLS 3(PLS_SEM), Gotop, Taipei City.

Xie, Q. (2003). The impact of organizational political perception on organizational commitment, job performance, organizational citizenship behavior: A comparative analysis of membership of citizenship enterprises. Doctoral Dissertation, Ching-I Hsieh.

Yang, Y. (2004). Perception of organizational support and the effect of exchanges between leaders and subordinates on organizational citizenship behavior. Taiwan Academy of Management Journal, 4(2), 141-160.

Yoon, D., Yoon, D., Jang, J., Jang, J., Lee, J., \& Lee, J. (2016). Environmental management strategy and organizational citizenship behaviors in the hotel industry: The mediating role of organizational trust and commitment. International Journal of Contemporary Hospitality Management, 28(8), 1577-1597. https://doi.org/10.1108/JCHM-10-2014-0498

Zhao, Z., Yang, Z., \& Kong, X. (2016). International corporate social responsibility trends and expectations for Taiwan's future development. CSR Summit for Entrepreneur Cross-Strait Cooperation Journal, 1(1), 74-89.

Zheng, Y., Xu, W., \& Qiu, X. (2015). Effect of teacher organizational trust, organizational commitment, and campus organizational atmosphere on work satisfaction. Chaoyang Journal of Humanities and Social Sciences, 13(2), 97-116.

Zhou, C., \& Chen, Y. (2009). Effect of internal marketing in the chain food and beverage industry on employee organizational citizenship behavior. Journal of SME Development, $1(11), 141-168$.

Zhou, C., \& Wu, J. (2010). Effects of corporate social responsibility on employee organizational citizenship behavior. paper presented at 2010 Sustainable Product and Industry Management Seminar and Sustainable Innovation Forum. March 19, 2003, National Yunlin University of Science and Technology. Retrieved Sept. 6, 2017 from: http://www2010.yuntech.edu.tw/index.php?option=com_content\&task=view\&id=10116\&Ite $\operatorname{mid}=1055$.

Zhuo, Z., Wei, X., \& Guo, H. (2015). The relationship between perceived organizational 
support and organizational citizenship behavior: With emotional organizational commitment as a mediator variable. Management Information Computing, 4(1), 28-41.

\section{Copyright Disclaimer}

Copyright for this article is retained by the author(s), with first publication rights granted to the journal.

This is an open-access article distributed under the terms and conditions of the Creative Commons Attribution license (http://creativecommons.org/licenses/by/4.0/). 